\title{
Lessons from COVID-19 and Seoul: Effects of Reduced Human Activity from Social Distancing on Urban $\mathrm{CO}_{2}$ Concentration and Air Quality
}

Special Issue:

Special Issue on COVID-19 Aerosol Drivers, Impacts and Mitigation (IX)

\author{
Hayoung Park ${ }^{1}$, Sujong Jeong ${ }^{1 *}$, Ja-Ho Koo ${ }^{2}$, Sojung Sim ${ }^{1}$, Yeon Bae ${ }^{1}$, \\ Yeonsoo Kim ${ }^{1}$, Chaerin Park ${ }^{1}$, Jeongyeon Bang ${ }^{1}$ \\ ${ }^{1}$ Department of Environmental Planning, Graduate School of Environmental Studies, Seoul \\ National University, Seoul, Korea \\ ${ }^{2}$ Department of Atmospheric Sciences, Yonsei University, Seoul, Korea
}

\section{OPEN ACCESS}

Received: July 5, 2020

Revised: September 23, 2020

Accepted: September 29, 2020

* Corresponding Author: sujong@snu.ac.kr

\section{Publisher:}

Taiwan Association for Aerosol Research

ISSN: $1680-8584$ print

ISSN: 2071-1409 online

Copyright: The Author(s). This is an open access article distributed under the terms of the Creative Commons Attribution License (CC BY 4.0), which permits unrestricted use, distribution, and reproduction in any medium, provided the original author and source are cited.

\section{ABSTRACT}

Social restriction in cities to curb infection rates of COVID-19 has become an opportunity to investigate the relationship between humans and the urban atmosphere. We evaluate the impact of the decline in human activities as a result of social distancing on the urban $\mathrm{CO}_{2}$ concentrations and air quality in Seoul during February and March of 2020 compared to 2019. Due to the reduction in human activity in 2020, local measurements of $\mathrm{CO}$ and $\mathrm{NO}_{2}$ show a decrease in background concentration (up to $-11.9 \%$ and $-41.7 \%$, respectively) and urban enhancement (up to $-16.7 \%$ and $-38.1 \%$, respectively) compared to the previous year. In contrast, the background concentration of $\mathrm{CO}_{2}$ increases by $3.9 \%$ in 2020. Ratios of $\mathrm{CO}: \mathrm{CO}_{2}$ and $\mathrm{NO}_{2}: \mathrm{CO}_{2}$ also show a decrease in 2020 compared to the previous year, signaling an improvement in the urban air quality of Seoul. Moreover, the insignificant change in wind speed and wind direction during the months of February and March 2020 compared to $2019 \mathrm{implies}$ that $\mathrm{CO}_{2}$, $\mathrm{CO}$, and $\mathrm{NO}_{2}$ concentrations have not been influenced by meteorological conditions, but mainly by changes in emissions from decreased human activity. Despite the rise in background $\mathrm{CO}_{2}$ concentration, urban contributions of $\mathrm{CO}_{2}$ show a decline of $-12.6 \%$, indicating that cities with high emissions have the potential to reduce urban $\mathrm{CO}_{2}$ enhancements and air pollutant concentrations, and ultimately impact the global atmosphere.

Keywords: COVID-19, Social distancing, Urban emissions, Air quality

\section{INTRODUCTION}

On 11 March 2020, the Word Health Organization (WHO) declared the highly infectious novel Coronavirus disease 2019 (COVID-19) as a global pandemic (WHO, 2020a). As of 1 September 2020, over 1.8 million new COVID-19 cases and 38,000 new deaths have been reported from across the world (WHO, 2020b). The emergence of COVID-19 has resulted in countries taking various emergency measures to contain the virus from spreading, ranging from social distancing to shelter-in-place regulations, and even drastic government orders of a complete quarantine or lockdown of entire cities. Such orders have led to a slowdown in economic activity as well as a substantial decrease in human activity. Subsequently, the reduction in everyday human activity has caused a significant change in the atmosphere across the globe, with reports of decreases in greenhouse gas and air pollutant emissions (Bauwens et al., 2020; Le Quéré et al., 2020; Shi and Brasseur, 2020; Xu et al., 2020a; Xu et al., 2020b; Zhang et al., 2020). In particular, as urban air quality is heavily dependent on human activities such as vehicle use, home heating, and industrial activity (Clerbaux et al., 2008; Lamsal et al., 2013), social restrictions in cities to "flatten the curve" and slow down the spread of the virus has become a prime opportunity for a natural experiment to observe the relationship between human activity and the urban atmosphere, and 
further explore the possibility of mitigating climate change. However, recent studies on COVID-19 have mostly focused on emission reductions, while analysis of atmospheric concentrations of gases and their impact on air quality is still in need.

As the source of more than $70 \%$ of greenhouse gas and air pollutant emissions, cities are the best places to see the interaction between anthropogenic activity and its impact on the urban atmosphere (UN Habitat, 2011; Duren and Miller, 2012). Seoul, a megacity with over 9 million inhabitants, is deemed as one of the biggest emitters of $\mathrm{CO}_{2}$ and air pollutants among other cities in the world (Moran et al., 2018). At the end of February 2020, the South Korean government followed the advice of the Korea Centers for Disease Control and Prevention (KCDC) and raised the infectious disease crisis warning to the highest level, issuing intense social distancing policies and closing down schools, non-essential businesses, and religious facilities. This also led to the restriction of outdoor activities, gatherings, and travel, causing many people to stay indoors. Thus, Seoul became an ideal setting to measure what effects decreased human activity as a result of social distancing have on the urban atmosphere and air quality.

In this study, we evaluate the impact of the decline in human activity due to social distancing on the urban atmosphere of Seoul during February and March of 2020 in comparison to the respective months of 2019. We investigate the changes in socioeconomic data of traffic volume, floating population, and energy consumption before and after the implementation of social distancing. In addition, using the established network of available ground measurements and satellite data, we assess various aspects of the local atmosphere of Seoul from a representative greenhouse gas, $\mathrm{CO}_{2}$, to air pollutants, $\mathrm{CO}$ and $\mathrm{NO}_{2}$, during our period of study to observe the impacts of reduced human activity on the urban air quality.

\section{METHODS}

We focus our study on the impact of human activity on the concentrations of $\mathrm{CO}_{2}$ and air pollutants $\mathrm{CO}$ and $\mathrm{NO}_{2}$. Data on local $\mathrm{CO}_{2}$ concentrations from ground measurements in Seoul are available starting from 2019. Therefore, the following data used in this study is between 2019 and 2020, which is consistent with the period of data obtained from $\mathrm{CO}_{2}$ measurements.

\subsection{Socioeconomic Data}

We use the socioeconomic data of traffic volume, floating population, and energy consumption, which most visibly represent the amount of human activity in Seoul during February and March of 2019 and 2020. The total weekly volume of on-road traffic is obtained from the Seoul Transport Operation \& Information Service (TOPIS) data on daily count of on-road vehicles. The number of vehicles passing in front of the detectors installed on major highways and urban expressways in Seoul are counted consecutively at one-hour intervals and made public on the TOPIS official website (https://topis.seoul.go.kr). Floating population data for the districts of Seoul are retrieved from the Seoul Open Data Platform (https://data.seoul.go.kr). Floating population refers to the total amount of pedestrian traffic occurring in a unit area or specific location at a given time, and this number is estimated by the Seoul Metropolitan Government in cooperation with the mobile carrier KT using public big data from KT mobile phones and LTE signals that are owned by the Seoul Metropolitan Government (Jeong and Moon, 2014). Lastly, the monthly electric consumption data by energy sector is retrieved from the Korea Electric Power Corporation (KEPCO), which supplies the nation's electric power (https://bigdata.kepco.co.kr).

\subsection{Ground Observations}

$\mathrm{CO}_{2}$ is a long-lived, chemically stable species often co-emitted with other pollutants during anthropogenic activities such as fossil fuel combustion, and can be used as indicators of other pollutants in urban atmospheric monitoring (Wunch et al., 2009). We use the hourly-averaged $\mathrm{CO}_{2}$ data measured on the rooftop of a tall building in Yongsan located in the center of Seoul $\left(37^{\circ} 31^{\prime} 26^{\prime \prime} \mathrm{N}, 126^{\circ} 57^{\prime} 49^{\prime \prime} \mathrm{E}\right.$ and $113 \mathrm{~m}$ a.s.l). The equipment installed is an $\mathrm{LI}-850$ (LI-COR CO $2 / \mathrm{H}_{2} \mathrm{O}$ analyzer), which provides a continuous monitoring of $\mathrm{CO}_{2}$ with a temporal resolution of 1 minute (Park et al., 2020). To compare air pollutants with the measured $\mathrm{CO}_{2}$, we selected the nearest air 
quality monitoring station located $3.9 \mathrm{~km}$ away $\left(37^{\circ} 32^{\prime} 24^{\prime \prime} \mathrm{N}, 127^{\circ} 00^{\prime} 18^{\prime \prime} \mathrm{E}\right.$ and $62 \mathrm{~m}$ a.s.l). The urban air quality monitoring station, operated by the Seoul Institute for Health and Environment, is used to observe average air pollutant concentrations in areas around Seoul and determine whether environmental standards are achieved. Two of the criteria air pollutants measured at the urban air quality monitoring station, $\mathrm{CO}$ and $\mathrm{NO}_{2}$, are used in this study. $\mathrm{CO}$ is produced from combustion processes where the relative amount of $\mathrm{CO}$ is contingent on the efficiency and completeness of the combustion and acts a suitable tracer for pollutant emissions and transport (Turnbull et al., 2011; Silva et al., 2013). $\mathrm{NO}_{2}$ is formed and emitted to the atmosphere when fossil fuels are combusted at high temperatures and, due to its short chemical lifetime, is concentrated near its emission sources, making it advantageous in estimating anthropogenic emissions from fossil fuel combustion (Richter et al., 2005; Silva et al., 2017). Thus, the amount of $\mathrm{NO}_{2}$ usually reflects the emissions of traffic activity and power plant operations well. The instruments installed at the air quality monitoring stations for $\mathrm{CO}$ is the KIMOTO CO analyzer (CA-751), which uses the non-dispersive infrared method, and for $\mathrm{NO}_{2}$ is the KIMOTO NO analyzer (NA-721), which uses the chemiluminescent method. The daily, hourly-averaged data is retrieved from AIRKOREA (www.airkorea.or.kr), the open-access website that publishes real-time air pollution information. All ground datasets in this study are widely used in air quality research in Seoul (Choi et al., 2014; Kim et al., 2014; Ghim et al., 2015; Sim et al., 2020).

Due to its characteristics of being long-lived and chemically stable, $\mathrm{CO}_{2}$ is well-mixed with biospheric fluxes and the effects of long-range transport. Therefore, such influences must be put into consideration and background concentrations should be removed in the assessment of urban $\mathrm{CO}_{2}$ concentrations (Kort et al., 2012; Briber et al., 2013; Hutyra et al., 2014). We used the method of Bares et al. (2018) to extract the urban enhancement values of each species and disentangle the contribution of recently emitted pollutants in urban areas from background values. We define the background concentration as the lowest first percentile concentration within a $24 \mathrm{~h}$ window of the measured data, which is then subtracted from each data point to determine the excess concentrations due to urban emissions (i.e., urban enhancements) of each species.

Furthermore, measurements of both greenhouse gases and air pollutants on the ground allow a comparison of air quality using the ratios of $\mathrm{CO}: \mathrm{CO}_{2}$ and $\mathrm{NO}_{2}: \mathrm{CO}_{2}$. As air pollutants share common combustion sources with anthropogenic $\mathrm{CO}_{2}$, comparing $\mathrm{CO}_{2}$ together with $\mathrm{CO}$ and $\mathrm{NO}_{2}$ allows us to characterize emission sources and assess their link to air quality (Konovalov et al., 2016). Multiple studies have utilized the ratios of trace gases to urban enhancements of anthropogenic $\mathrm{CO}_{2}$ concentrations to analyze air quality in cities (Suntharalingam et al., 2004; Worden et al., 2012; Silva et al., 2017; Bares et al., 2018). We carried out a regression analysis and calculated the slope to define the emission ratios of the observed $\mathrm{CO}_{2}$ to air pollutants $\mathrm{CO}$ and $\mathrm{NO}_{2}$.

\subsection{Satellite Observations}

The Tropospheric Monitoring Instrument (TROPOMI) onboard the Copernicus Sentinel-5 Precursor satellite, launched in October 2017, is a sun-synchronous nadir-looking grating spectrometer that performs measurements of the solar light reflected by the Earth's atmosphere in the UV-VIS (270-495 nm), NIR (710-775 nm), and SWIR (2305-2385 nm) spectral domain (Veefkind et al., 2012). The large swath and high signal-to-noise ratio of the instrument enable daily global observations of air quality and detection of trace gases using single orbit overpasses (Borsdorff et al., 2019). We use the high spatial resolution column data measurements of CO (5.5 km $\times 7 \mathrm{~km}, \mathrm{SWIR})$ and $\mathrm{NO}_{2}(5.5 \mathrm{~km} \times 3.5 \mathrm{~km}, \mathrm{UVN})$ collected from Seoul and the surrounding Gyeonggi-do Province during February to March of 2019 and 2020. We use data with the recommended quality assurance value greater than 0.75 for all the overpasses used in our study. Multiple studies have used TROPOMI $\mathrm{CO}$ and $\mathrm{NO}_{2}$ retrievals to study top-down emission characteristics in megacities as well as to determine impacts on air quality (Goldberg et al., 2019; Lama et al., 2019; Bauwens et al., 2020).

\subsection{Meteorological Data}

Meteorological data such as wind direction and wind speed are obtained from the Automatic Weather System (AWS) located near the Yongsan $\mathrm{CO}_{2}$ measurement site $\left(37^{\circ} 31^{\prime} 13.4^{\prime \prime} \mathrm{N}\right.$ 
$126^{\circ} 58^{\prime} 34.0^{\prime \prime} \mathrm{E}$ and $32 \mathrm{~m}$ a.s.l). Wind speed and wind direction data are collected at one-minute intervals and averaged to hourly observations. The data can be retrieved from the Korea Meteorological Administration National Climate Data Center (https://data.kma.go.kr/).

\section{RESULTS}

\subsection{Reductions in Human Activity}

To observe the changes in the traffic volume in Seoul, we compared the total number of vehicles on-road Seoul during the two years of the period of study. Figs. 1(a) and 1(b) show the weekly total traffic volume in Seoul from February to March for 2019 and 2020. Compared to the previous year, the traffic volume in February and March of 2020 shows a decrease of $-3.6 \%$ and $-8.9 \%$, respectively. Aside from Monday to Wednesday, there is an overall decline in traffic volume in February 2020 compared to February 2019. The decrease in traffic volume from
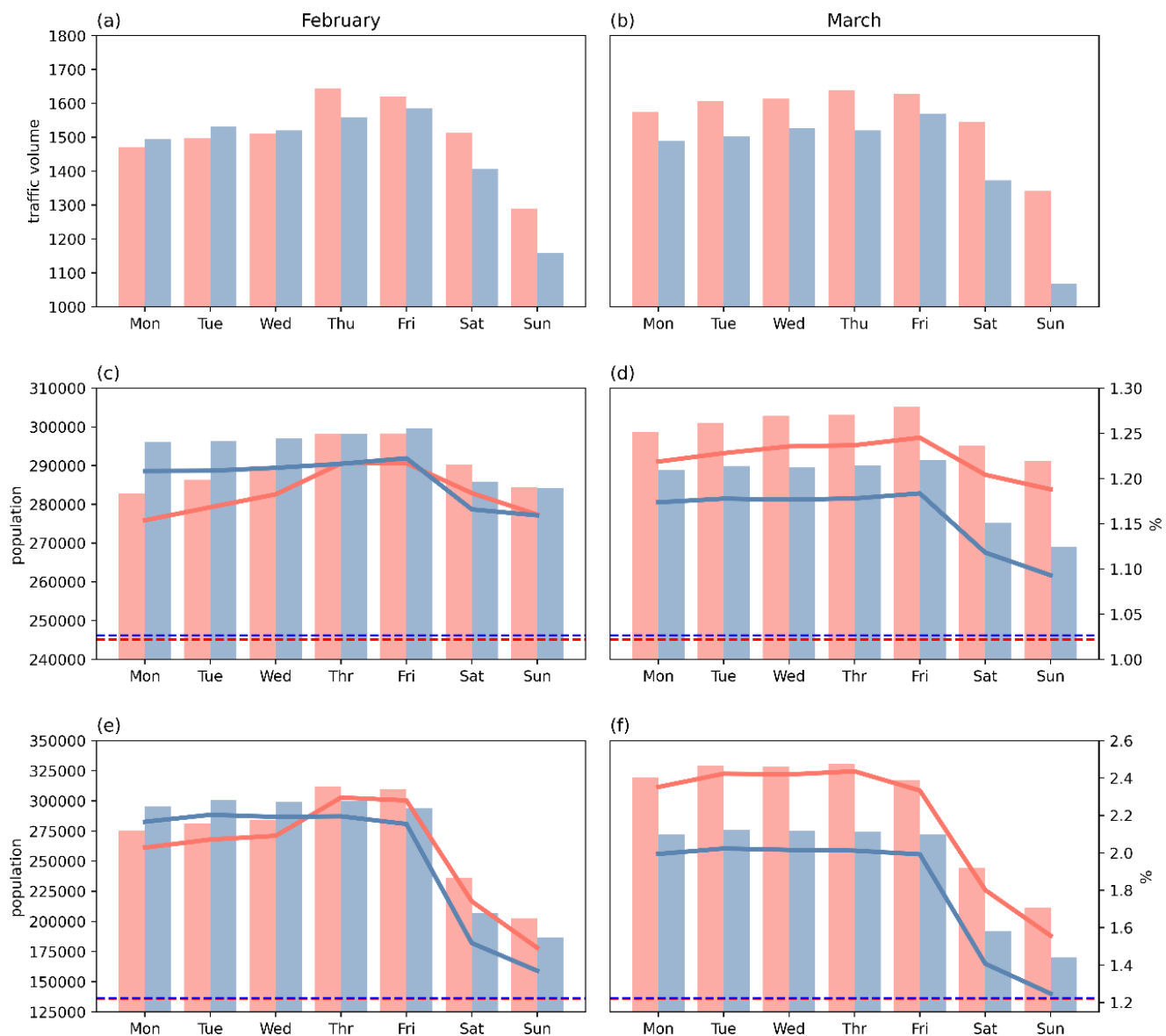

$$
2019-2019 \text { floating population ratio --- 2019_resident population }
$$

Fig. 1. Socioeconomic data of traffic volume and floating population representing human activity in Seoul. Weekly total count of traffic volume in Seoul is presented in (a) for February and (b) for March of 2019 and 2020. Comparison of weekly floating population data of Yonsan-gu is displayed in (c) for February and (d) for March of the years 2019 and 2020, and weekly floating population data of Jung-gu is displayed in (e) for February and (f) for March of the years 2019 and 2020. Bars indicate the total count of traffic volume and floating population, bold lines indicate the ratio of floating population over residing population, and dotted lines indicate resident population of the area. Orange represents the year 2019 and blue represents the year 2020. 
Monday to Wednesday in 2019 compared to the subsequent year can be explained by the Korean Lunar New Year, which was celebrated from 4-6 February 2019. In March 2020, there is a significant reduction in traffic volume for both weekdays and weekends in comparison to the corresponding months of the prior year.

Next, we estimate the dispersion of human activity in Seoul by analyzing the floating population data by district. We present the floating population data of Yongsan-gu, the district where the ground measurements are located, and Jung-gu, one of the most densely populated areas in Seoul, for February and March of 2019 and 2020 (Figs. 1(c) to 1(f)). Yongsan-gu is a district with a combination of commercial areas and residential areas. In February 2020, the floating population of Yongsan-gu does not show much difference to the year prior. Only the weekends have a slighter decrease of $-0.8 \%$, while weekdays show an increase of $2.2 \%$ in floating population compared to the same month of 2019. On the other hand, in March 2020, the floating population of Yongsan-gu has a decrease of $-4.1 \%$ during the weekdays and a decrease of $-7.2 \%$ during the weekends compared to the previous year. In addition, the ratio of the floating population per residential population in 2020 has a decline of $-11 \%$ compared to 2019 . Jung-gu is a business district located in the center of Seoul with various offices and large shopping malls concentrated in the area. The district also shows a similar pattern to that of Yongsan-gu where the floating population increases by $1.8 \%$ during the weekdays and decreases by $-10.3 \%$ in the weekends in February 2020 compared to 2019. In March 2020, however, the floating population shows a greater change compared to that of the previous year with a $-15.7 \%$ and $-20.6 \%$ decrease during the weekdays and weekends, respectively, with also a $-23 \%$ decrease in the ratio of the floating population per residential population.

Finally, we observe the monthly data of total electric consumption per industrial sector in Seoul (Table 1). Overall, there is a reduction in the total amount of electric consumption in February (-5 MWh) and March (-6 MWh) in 2020 compared to 2019. By sector, the largest decrease in energy usage is in educational services; wholesale and retail trade; accommodation and restaurants; electricity, gas, steam and waterworks; and manufacturing. The educational sector has the largest decrease in electricity consumption with $-9,160 \mathrm{MWh}(-5.3 \%)$ in February 2020 and $-18,040$ MWh (-12.2\%) in March of 2020 as schools were closed down due to COVID-19 with the beginning of the school year postponed indefinitely. Businesses such as restaurants, accommodation, and other service-related enterprises also faced difficulties as customers subsided, which is reflected in the data of energy usage. In contrast, sectors such as health and social welfare services (1,967 MWh (1.9\%) in February and 6,651 MWh (7.2\%) in March); scientific and technical services (60 MWh (0.2\%) in February and 1,447 MWh (4.3\%) in March); and broadcasting and publishing (11,740 MWh in February (8.6\%) and 10,155 MWh (7.4\%) in March) display a dramatic increase in energy consumption in 2020 compared to the previous year. Especially, energy consumption data for the year 2020 reflects the escalation of emergencies in public health facilities and the rigorous broadcasting of news events as well as the upsurge of scientific research on virus testing kits and vaccine development.

\subsection{Changes in Urban $\mathrm{CO}_{2}$ Concentrations and Air Quality}

To observe the changes in $\mathrm{CO}_{2}$ concentrations and air quality in the urban atmosphere during the period coinciding with the reduction of human activity, we examine average concentration, background concentration, and excess concentration of $\mathrm{CO}_{2}, \mathrm{CO}$, and $\mathrm{NO}_{2}$ from ground observations which are presented in Table 2. In February 2020, the average, background, and excess concentrations of all the measured atmospheric constituents show an overall decrease compared to the previous year. Among the three measured species, $\mathrm{NO}_{2}$ displays the largest decrease of $-32.9 \%$ and $-32.7 \%$ in average concentration and background concentration, respectively. $\mathrm{CO}$ has a decrease of $-14.1 \%$ and $-9.1 \%$ in average concentration and background concentration, respectively, and $\mathrm{CO}_{2}$ has the least reduction of $-0.2 \%$ and $-0.1 \%$ in average concentration and background concentration, respectively. The excess concentrations of all the measured species are lower in February 2020 compared to 2019 with decreases of $-34 \%,-23.8 \%$, and $-4.4 \%$ for $\mathrm{NO}_{2}, \mathrm{CO}$, and $\mathrm{CO}_{2}$, respectively.

In March of 2020, $\mathrm{CO}$ and $\mathrm{NO}_{2}$ exhibit a drop in average concentration, background concentration, and excess concentration. Compared to the previous year, $\mathrm{CO}$ has a decrease of $-15.3 \%$ and $-11.9 \%$ 
Table 1. Total electric consumption data of Seoul by sector for February and March 2019 and 2020. The amount of change indicates the difference in electricity consumption of 2020 compared to 2019.

\begin{tabular}{|c|c|c|c|c|c|c|}
\hline \multirow{2}{*}{ Industrial Classification } & \multicolumn{4}{|c|}{ Electricity Consumption (kWh) } & \multicolumn{2}{|c|}{ Amount of change } \\
\hline & February 2019 & March 2019 & February 2020 & March 2020 & February & March \\
\hline Construction & $52,146,587$ & $47,494,631$ & $51,627,623$ & $48,960,630$ & $-518,964$ & $1,465,999$ \\
\hline Public administration & $60,697,058$ & $51,108,081$ & $58,962,338$ & $51,489,371$ & $-1,734,720$ & 381,290 \\
\hline Mining & 373,681 & 295,765 & 379,777 & 342,347 & 6,096 & 46,582 \\
\hline Educational service & $174,132,523$ & $148,087,253$ & $164,973,011$ & $130,047,322$ & $-9,159,512$ & $-18,039,931$ \\
\hline $\begin{array}{l}\text { International and foreign } \\
\text { institutions }\end{array}$ & $7,336,813$ & $6,057,210$ & $5,537,697$ & $4,656,632$ & $-1,799,116$ & $-1,400,578$ \\
\hline Financial and Insurance & $36,008,866$ & $33,962,056$ & $35,746,840$ & $34,223,872$ & $-262,026$ & 261,816 \\
\hline $\begin{array}{l}\text { Agriculture, Forestry, and } \\
\text { Fisheries }\end{array}$ & $1,631,929$ & $1,337,215$ & $1,527,845$ & $1,310,412$ & $-104,084$ & $-26,803$ \\
\hline Wholesale and Retail trade & $344,249,211$ & $294,171,911$ & $321,787,161$ & $286,261,614$ & $-22,462,050$ & $-7,910,297$ \\
\hline $\begin{array}{l}\text { Health and Social welfare } \\
\text { services }\end{array}$ & $101,999,608$ & $92,830,140$ & $103,966,272$ & $99,481,205$ & $1,966,664$ & $6,651,065$ \\
\hline Real estate and Buy-to-let & $1,024,379,018$ & $870,776,420$ & $1,008,481,453$ & $891,702,001$ & $-15,897,565$ & $20,925,581$ \\
\hline Business facility management & $30,258,791$ & $25,668,611$ & $28,393,962$ & $25,089,937$ & $-1,864,829$ & $-578,674$ \\
\hline $\begin{array}{l}\text { Accommodation and } \\
\text { Restaurant }\end{array}$ & $207,188,286$ & $174,563,059$ & $192,617,573$ & $162,854,572$ & $-14,570,713$ & $-11,708,487$ \\
\hline $\begin{array}{l}\text { Arts, Sports, and Leisure- } \\
\text { related service }\end{array}$ & $54,385,073$ & $44,621,534$ & $49,677,591$ & $38,850,459$ & $-4,707,482$ & $-5,771,075$ \\
\hline Transportation & $193,534,634$ & $164,515,037$ & $188,315,612$ & $170,751,747$ & $-5,219,022$ & $6,236,710$ \\
\hline $\begin{array}{l}\text { Electricity, gas, steam and } \\
\text { waterworks }\end{array}$ & $92,878,142$ & $85,508,432$ & $85,855,141$ & $77,584,253$ & $-7,023,001$ & $-7,924,179$ \\
\hline $\begin{array}{l}\text { Scientific and technical } \\
\text { services }\end{array}$ & $36,884,024$ & $33,622,250$ & $36,944,098$ & $35,068,886$ & 60,074 & $1,446,636$ \\
\hline Manufacturing & $148,488,168$ & $131,884,466$ & $137,328,052$ & $129,378,363$ & $-11,160,116$ & $-2,506,103$ \\
\hline Broadcasting and Publishing & $135,939,439$ & $138,196,172$ & $147,679,671$ & $148,351,239$ & $11,740,232$ & $10,155,067$ \\
\hline Sewage treatment & $43,537,803$ & $46,184,974$ & $47,899,600$ & $48,965,313$ & $4,361,797$ & $2,780,339$ \\
\hline $\begin{array}{l}\text { Association, Organization, } \\
\text { and Personal service business }\end{array}$ & $91,565,429$ & $74,601,809$ & $84,935,828$ & $68,040,051$ & $-6,629,601$ & $-6,561,758$ \\
\hline Total & $2,837,631,284$ & $2,465,500,796$ & $2,752,648,344$ & $2,453,417,862$ & $-5,002$ & $-6,134$ \\
\hline
\end{tabular}

Table 2. Results of average concentration (Avg. conc.), background concentration (Back. conc.), and excess concentration (Ex. conc.) of $\mathrm{CO}_{2}, \mathrm{CO}$, and $\mathrm{NO}_{2}$ from ground measurements during February and March of 2019 and 2020, respectively. Ratio indicates percentage change in concentrations in 2020 compared to 2019.

\begin{tabular}{|c|c|c|c|c|c|c|c|c|c|c|}
\hline \multirow{2}{*}{ Gas } & & \multicolumn{3}{|c|}{2019} & \multicolumn{3}{|c|}{2020} & \multicolumn{3}{|c|}{ Ratio of 2020 relative to 2019} \\
\hline & & Avg. conc. & Back. conc. & Ex. conc. & Avg. conc. & Back. conc. & Ex. conc. & Avg. conc. & Back. Conc. & Ex. conc. \\
\hline & $\mathrm{CO}_{2}(\mathrm{ppm})$ & 449.61 & 427.85 & 23.73 & 448.87 & 427.28 & 22.69 & $-0.16 \%$ & $-0.13 \%$ & $-4.38 \%$ \\
\hline \multirow[t]{3}{*}{ Feb } & $\mathrm{CO}(\mathrm{ppm})$ & 0.64 & 0.44 & 0.21 & 0.55 & 0.40 & 0.16 & $-14.06 \%$ & $-9.09 \%$ & $-23.81 \%$ \\
\hline & $\mathrm{NO}_{2}(\mathrm{ppb})$ & 40.83 & 24.22 & 17.29 & 27.39 & 16.29 & 11.42 & $-32.92 \%$ & $-32.74 \%$ & $-33.95 \%$ \\
\hline & $\mathrm{CO}_{2}(\mathrm{ppm})$ & 443.17 & 424.63 & 19.36 & 457.20 & 440.96 & 16.92 & $3.16 \%$ & $3.85 \%$ & $-12.60 \%$ \\
\hline \multirow[t]{2}{*}{ Mar } & $\mathrm{CO}(\mathrm{ppm})$ & 0.59 & 0.42 & 0.18 & 0.50 & 0.37 & 0.15 & $-15.25 \%$ & $-11.90 \%$ & $-16.67 \%$ \\
\hline & $\mathrm{NO}_{2}(\mathrm{ppb})$ & 39.64 & 22.68 & 17.55 & 23.82 & 13.23 & 10.87 & $-39.91 \%$ & $-41.67 \%$ & $-38.06 \%$ \\
\hline
\end{tabular}

for average concentration and background concentration, respectively. In comparison, $\mathrm{NO}_{2}$ has a substantial decline of $-39.9 \%$ and $-41.7 \%$ of average concentration and background concentration, respectively. The excess concentrations for both $\mathrm{CO}$ and $\mathrm{NO}_{2}$ have a reduction of $-16.7 \%$ and $-38.1 \%$, respectively, compared to March of the previous year. On the other hand, in March 2020, $\mathrm{CO}_{2}$ displays an increase in both average concentration and background concentration with a rise of $3.2 \%$ and $3.9 \%$, respectively, compared to the corresponding month in 2019 . However, despite the rise in average and background concentrations of $\mathrm{CO}_{2}$, the excess concentration of $\mathrm{CO}_{2}$ 
continues to decline from February $(-4.4 \%)$ and well into March $(-12.6 \%)$ of 2020 . In other words, although the background concentration of $\mathrm{CO}_{2}$ increased in 2020, the urban enhancement of $\mathrm{CO}_{2}$ maintains a pattern of decrease like the air pollutants $\mathrm{CO}$ and $\mathrm{NO}_{2}$ compared to the previous year.

We further examine the urban enhancement ratios of $\mathrm{CO}: \mathrm{CO}_{2}$ and $\mathrm{NO}_{2}: \mathrm{CO}_{2}$ of February and March for both 2019 and 2020 to assess the impact on urban air quality as shown in Fig. 2. For both months, air pollutants $\mathrm{CO}$ and $\mathrm{NO}_{2}$ per $\mathrm{CO}_{2}$ show a decrease in slopes in 2020 as opposed to 2019 . Compared to the previous year, the ratio of $\mathrm{CO}: \mathrm{CO}_{2}$ decreases by $-20.8 \%$ and $-7.4 \%$ in February and March 2020, and the ratio of $\mathrm{NO}_{2}: \mathrm{CO}_{2}$ decreases by $-35.7 \%$ and $-16.7 \%$ in February and March 2020, respectively. This signifies that the concentration of air pollutants in the atmosphere has reduced more rapidly during the two months of 2020 compared to that of 2019 than the concentration of carbon dioxide which is stable and stays in the atmosphere for a considerable amount of time.

Finally, we observe satellite observations of the average concentrations of air pollutants CO and $\mathrm{NO}_{2}$ over Seoul and the surrounding Gyeonggi-do Province for the corresponding months of the period of study as presented in Fig. 3. Consistent with the ground measurement results, satellite observations show a decrease in $\mathrm{CO}$ and $\mathrm{NO}_{2}$ both in February and March 2020 compared to the previous year. In 2020, CO has an average decrease of $-5.6 \times 10^{-3} \mathrm{~mol} \mathrm{~m}^{-2}$ $(-11.5 \%)$ in February and $-3.8 \times 10^{-3} \mathrm{~mol} \mathrm{~m}^{-2}(-8.2 \%)$ in March, and $\mathrm{NO}_{2}$ has an average decrease of $-6.5 \times 10^{-5} \mathrm{~mol} \mathrm{~m}^{-2}(-28.1 \%)$ in February and $-8.5 \times 10^{-6} \mathrm{~mol} \mathrm{~m}^{-2}(-4.6 \%)$ in March

(a)

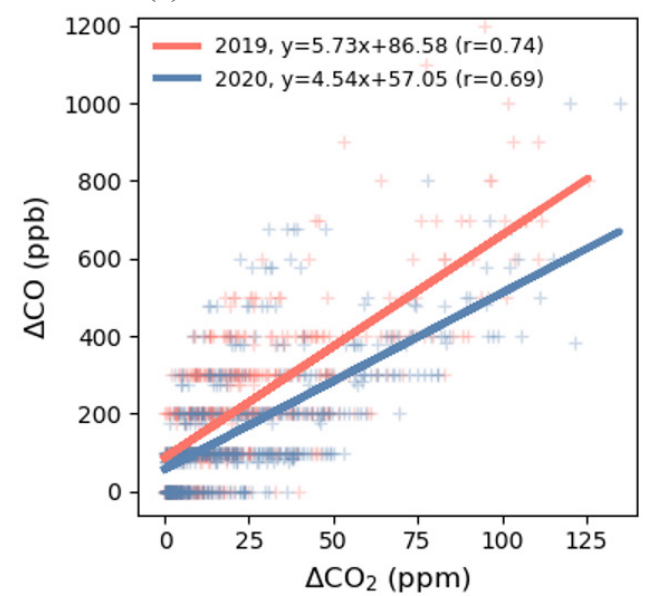

(c)

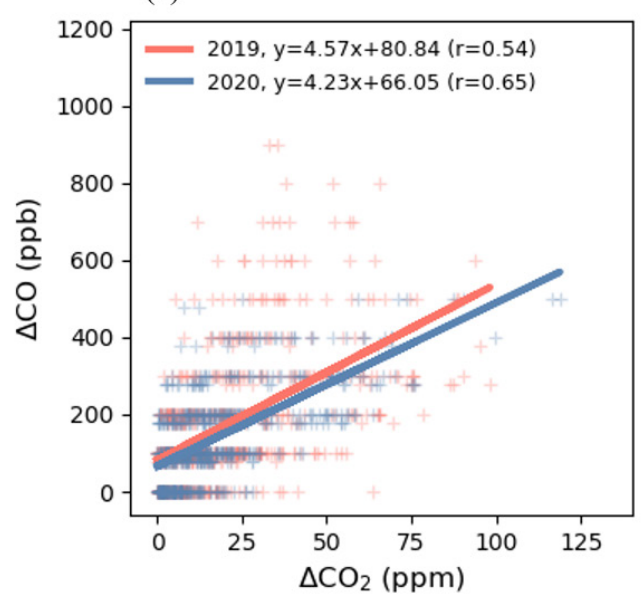

(b)

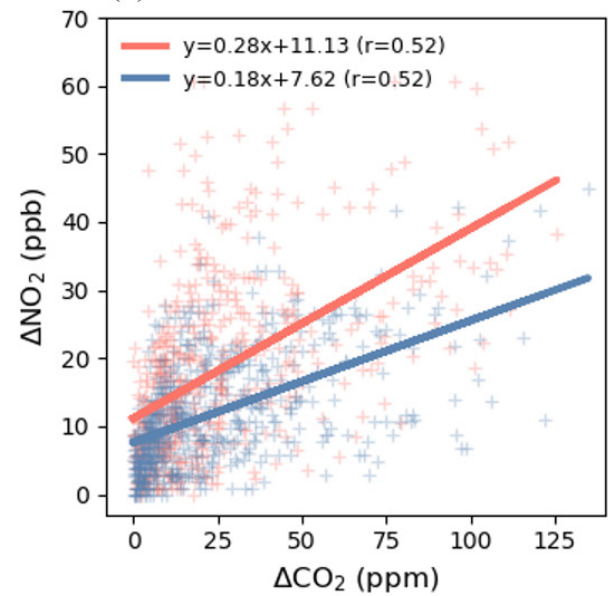

(d)

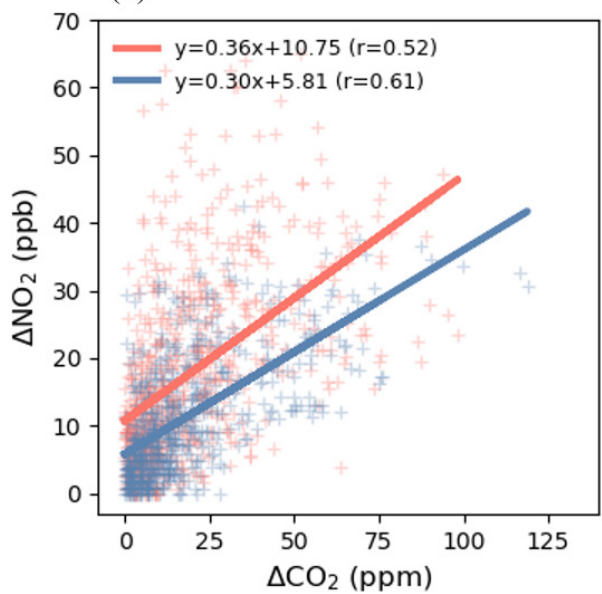

Fig. 2. Urban enhancement ratios of (a) $\mathrm{CO}: \mathrm{CO}_{2}$ and (b) $\mathrm{NO}_{2}: \mathrm{CO}_{2}$ of February 2019 and 2020 and urban enhancement ratios of (c) $\mathrm{CO}: \mathrm{CO}_{2}$ and (d) $\mathrm{NO}_{2}: \mathrm{CO}_{2}$ of March 2019 and 2020. Bold lines represent the slopes of the ratios. Orange indicates the year 2019 and blue indicates the year 2020. 

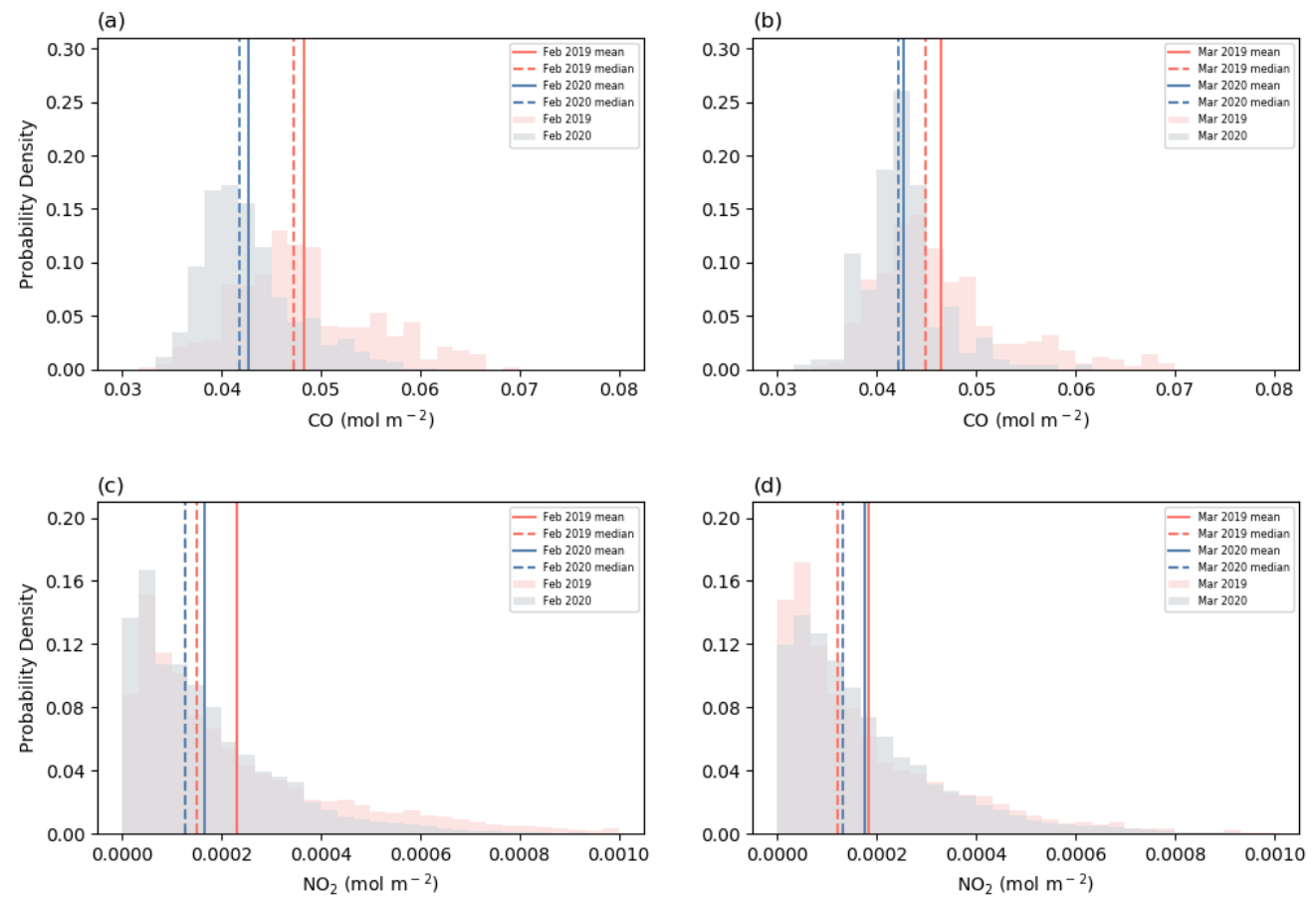

Fig. 3. S-5P TROPOMI satellite observations of Seoul and the surrounding Gyeonggi-do Province of average CO concentrations in (a) February and (b) March of 2019 and 2020, and observations of average $\mathrm{NO}_{2}$ concentrations of (c) February and (d) March of 2019 and 2020.

in comparison to the previous year. Similar to the urban enhancement ratios measured from the ground, top-down satellite observations of $\mathrm{CO}$ and $\mathrm{NO}_{2}$ also display an overall decrease in the urban atmosphere in 2020.

Meteorological conditions such as wind speed and wind direction play an important role in dispersing pollutants and creating favorable conditions for heavy pollution events within cities (Xu et al., 2020c). To evaluate the influence of dispersion conditions, we observe the effect of local meteorology on the concentrations of $\mathrm{CO}_{2}, \mathrm{CO}$, and $\mathrm{NO}_{2}$ in Seoul for both 2019 and 2020 (Fig. 4). Local wind speed and wind direction show that meteorological conditions have no significant change in 2020 from the previous year. Wind speed, which influence dispersion conditions, shows an average of $1.5 \pm 0.8 \mathrm{~m} \mathrm{~s}^{-1}$ and $1.9 \pm 1.2 \mathrm{~m} \mathrm{~s}^{-1}$ in February and March of 2019, respectively, while the average wind speed is $1.6 \pm 1.1 \mathrm{~m} \mathrm{~s}^{-1}$ and $2.0 \pm 1.3 \mathrm{~m} \mathrm{~s}^{-1}$ in February and March of 2020, respectively. Wind speed increased by $8.3 \%$ in February and $4.7 \%$ in March 2020 compared to the previous year; however, it is difficult to consider such increases to be statistically significant. Thus, minor changes in meteorological conditions indicate that the decrease of $\mathrm{CO}_{2}$, $\mathrm{CO}$, and $\mathrm{NO}_{2}$ concentrations in Seoul are mainly driven by the reductions in human activity due to social distancing.

\section{DISCUSSION AND CONCLUSIONS}

This study examined the impact of decreased human activity on the urban atmosphere of Seoul due to social distancing actions to prevent the spread of COVID-19 using data from various measurements. Results of traffic and floating population data show that there has been a significant decline in human activity in Seoul during February and March 2020 compared to the corresponding months in 2019. The South Korean government declared the highest level of alert for national action to fight against the infectious disease on 23 February 2020. Aside from the increase during the weekdays in February 2020, there is a steady decline in both traffic volume and floating population as fewer people moved around the city for work, leisure, or other activities. The reduced traffic volume and floating population from Monday to Wednesday in 

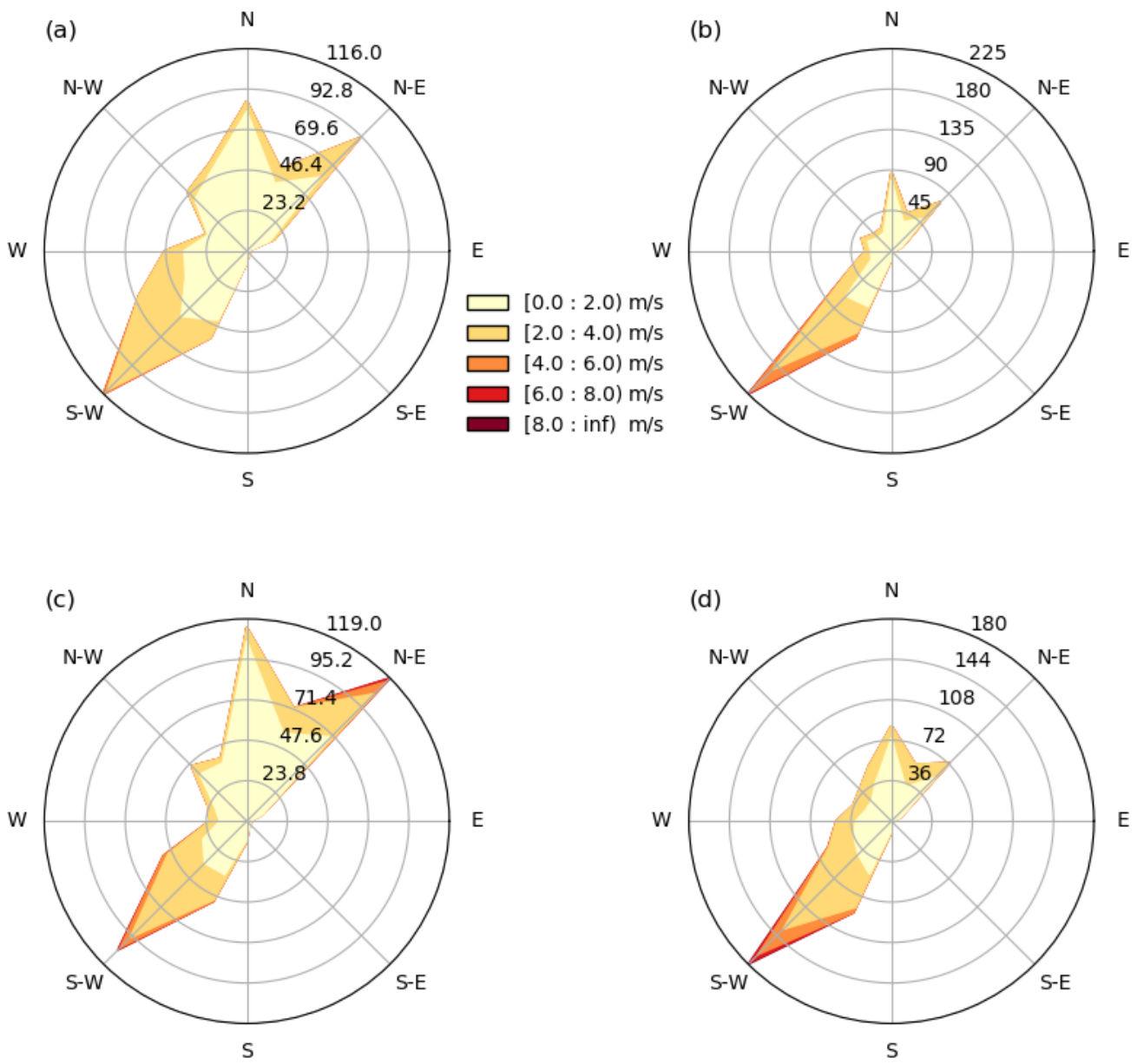

Fig. 4. Wind speed and wind direction of Seoul measured near the ground measurement sites during (a) February and (b) March of 2019 and (c) February and (d) March of 2020. The color bar represents strengths of wind speed.

February 2019 can be explained by the Korean Lunar New Year holiday, which was celebrated from Monday to Wednesday, 4-6 February 2019, in which during this period many people traveled to their hometowns outside of Seoul to visit family and relatives. The marked drop in both the average traffic volume and floating population is greater in March 2020 as more people worked from home and stayed indoors owing to the high-intensity social distancing policies imposed by the government starting mid-March.

Decreased human activity also resulted in less economic activity and energy consumption as schools and businesses closed down and fewer people traveled or visited non-essential businesses and facilities. The total energy consumption in Seoul decreases for both February and March of 2020 compared to the previous year, and this reduction is seen in almost all of the energy sectors. In contrast to the general decline of energy consumption, health and social welfare services as well as scientific and technical services have a considerable increase in energy consumption as hospitals and laboratories rushed to treat the surge of patients and develop testing kits and vaccines. The increase in energy consumption in such sectors accelerates in March as the spread of COVID-19 reaches its peak. In addition, the broadcasting and publishing sector also show a dramatic rise in energy consumption in February and March 2020 compared to the previous year as the government and broadcasting stations continued to announce and inform the public of the ongoing situation of the pandemic. The household energy consumption data, which could have been another indicator of the patterns of human activity during social distancing, was not available for analysis in our study. This can be considered for analysis in future studies when such data is accessible. Nonetheless, data on traffic volume, floating population, and energy consumption, which explain to an extent the amount of human activity in Seoul, exhibit a general 
decrease in all areas, confirming that the impact of COVID-19 and social distancing resulted in less human activity.

To observe the influence of decreased human activity on urban air quality, we analyze $\mathrm{CO}_{2}$ and air pollutants $\mathrm{CO}$ and $\mathrm{NO}_{2}$. In Seoul, both the concentrations of $\mathrm{CO}$ and $\mathrm{NO}_{2}$ measured from the ground show a decline in February and a more significant decrease in March 2020 compared to the previous year, following the pattern of traffic volume and floating population data. On-road vehicles and their fuel type are seen as one of the biggest contributors to urban air pollution (Mayer et al., 1999; Hassler et al., 2016). Seoul is densely populated with a large number of motor vehicles and traffic congestion, resulting in idling vehicles and high emissions of air pollutants (Nguyen et al., 2010; Kim and Guldmann, 2011; Kim et al., 2015). In a study using mobile and ground-based measurements to monitor the air quality and urban $\mathrm{CO}_{2}$ concentrations in Seoul, Sim et al. (2020) showed that vehicle emissions, particularly from diesel vehicles, are the major sources of emissions that impact the air quality of downtown Seoul during the wintertime. The larger decrease of air pollutants in March, especially of $\mathrm{NO}_{2}$, parallel the greater drop in traffic volume during the same month, demonstrating the close link of vehicle usage and air quality. This decline in air pollutant concentrations is also captured in satellite observations of Seoul and the surrounding area. Although satellite observations of air pollutant concentrations show a considerable decline in February, the decrease is smaller in March. Nonetheless, the overall pattern of decrease in 2020 compared to 2019 is shown for both months from satellite measurements. This difference can be due to the fact that ground-based observations are continuous measurements of local events, while satellite observations provide total column mixing ratios that are measured from the top of the atmosphere, which can be influenced by other meteorological events and do not immediately reflect surface-level emissions.

Decreases in urban enhancement ratios of $\mathrm{CO}: \mathrm{CO}_{2}$ and $\mathrm{NO}_{2}: \mathrm{CO}_{2}$ for both months in 2020 can also be explained by the effect of human activity on air quality. The decline of slopes of $\mathrm{CO}: \mathrm{CO}_{2}$ and $\mathrm{NO}_{2}: \mathrm{CO}_{2}$ in February and March 2020 compared to the corresponding months of the previous year indicates that the concentration of air pollutants per $\mathrm{CO}_{2}$ concentration in Seoul have decreased. This implies that the reduction of anthropogenic activity from social distancing has influenced the reduction of air pollutant concentration per $\mathrm{CO}_{2}$ concentration, resulting in an improvement in Seoul's air quality. Moreover, meteorological conditions remain the same in 2020 compared to the previous year, indicating that $\mathrm{CO}_{2}, \mathrm{CO}$, and $\mathrm{NO}_{2}$ concentrations have neither been greatly influenced by wind speed nor wind direction, but mainly by changes in emissions from decreased human activity.

Contrary to the large decrease of air pollutants in Seoul resulting from social distancing, average and background $\mathrm{CO}_{2}$ concentrations show a different pattern of change. In February 2020, $\mathrm{CO}_{2}$ concentrations show a slight decrease in average concentration and background concentration in Seoul compared to the previous year. However, despite the larger reduction of human activity, leading to a larger decline of air pollutants in March 2020, the average and background concentrations of $\mathrm{CO}_{2}$ increases compared to 2019. It is noteworthy that although there is a rise in the background $\mathrm{CO}_{2}$ concentration in March, the excess $\mathrm{CO}_{2}$ concentration, indicating the urban $\mathrm{CO}_{2}$ enhancement of Seoul, follows the general pattern of decrease along with the excess concentrations of air pollutants $\mathrm{CO}$ and $\mathrm{NO}_{2}$. Regardless of the rise in the background concentration, the urban enhancement of $\mathrm{CO}_{2}$ continues to show a steady decline due to decreased human activity such as vehicle use and energy consumption within the city during the enforcement of intensive social distancing policies. This decrease is consistent with the estimated decline in $\mathrm{CO}_{2}$ emissions that has also been observed by Le Quéré et al. (2020). Our results show that even with the intense cutback of human activities and emissions, background $\mathrm{CO}_{2}$ concentrations will continue to rise due to the long-lived characteristics of $\mathrm{CO}_{2}$ that remain in the atmosphere for about 120 years (Smith, 1993). However, the marked decline in urban enhancements of $\mathrm{CO}_{2}$ concentrations from social distancing emphasizes the potential of urban areas impacting and reducing local contributions of $\mathrm{CO}_{2}$ in the atmosphere with the decrease of emissions.

Despite limitations of the lack of data, our study presents various independent socioeconomic and atmospheric observation data which all point to the decreasing trend of values in 2020 compared to 2019. The reduction in human activity due to social distancing has led to a decrease of $\mathrm{CO}_{2}$ and air pollutants, strengthening the link between impacts of anthropogenic activity on 
the urban $\mathrm{CO}_{2}$ concentration and air quality, and demonstrating how intertwined everyday life and the use of fossil fuels have become. In contrast to the overall decrease of air pollutant concentrations in Seoul, the small impact that the curtailed human activity has on the background $\mathrm{CO}_{2}$ concentration implies that one country's effort to cut back emissions does not make a marked difference on the increasing trend of global background $\mathrm{CO}_{2}$ concentrations. However, this study presents that regardless of the increase in background $\mathrm{CO}_{2}$, the local enhancement of $\mathrm{CO}_{2}$ concentrations in Seoul show a significant decline along with the decrease of air pollutants. This highlights the importance of taking appropriate actions within cities to reduce anthropogenic activity which can effectively decrease urban air pollution and greenhouse gases. Moreover, this study also underlines the critical role and potential of cities in accelerating the decline of atmospheric greenhouse gases and air pollutants to improve urban air quality as well as to mitigate climate change.

\section{ACKNOWLEDGEMENTS}

This study was carried out with the support of 'R\&D Program for Forest Science Technology (Project No. 2019156A00-2021-0101)' provided by the Korea Forest Service (Korea Forestry Promotion Institute).

\section{DATA AVAILABILITY}

The high-resolution, real-time datasets are provided by the Seoul Metropolitan Government (https://data.seoul.go.kr/dataList/OA-15439/S/1/datasetView.do), Korea Electric Power Corporation (https://bigdata.kepco.co.kr/cmsmain.do?scode=S01\&pcode=000167), Seoul Transport Operation \& Information Service (https://topis.seoul.go.kr/refRoom/openRefRoom_2.do), and the Seoul Institute for Health and Environment (www.airkorea.or.kr). Meteorological data is retrieved from the Korea Meteorological Administration National Climate Data Center (https://data.kma.go.kr/ data/grnd/selectAwsRltmList.do?pgmNo=56). The $\mathrm{CO}_{2}$ data is from the Seoul National University $\mathrm{CO}_{2}$ Measurement $\left(\mathrm{SNUCO}_{2} \mathrm{M}\right)$ network operated by the Integrated Climate Science Lab (climatelab.snu.ac.kr). Sentinel-5 Precursor TROPOMI is part of the EU Copernicus program, and Copernicus Sentinel data 2019-2020 has been used (www.tropomi.eu). Datasets in this work are freely available from the provided website address or upon request.

\section{REFERENCES}

Bares, R., Lin, J.C., Hoch, S.W., Baasandorj, M., Mendoza, D.L., Fasoli, B., Mitchell, L., Catharine, D., Stephens, B.B. (2018). The wintertime covariation of $\mathrm{CO}_{2}$ and criteria pollutants in an urban valley of the Western United States. J. Geophys. Res. 123, 2684-2703. https://doi.org/10.100 2/2017JD027917

Bauwens, M., Compernolle, S., Stavrakou, T., Müller, J.F., Gent, J., Eskes, H., Levelt, P.F., A, R., Veefkind, J.P., Vlietinck, J., Yu, H., Zehner, C. (2020). Impact of coronavirus outbreak on $\mathrm{NO}_{2}$ pollution assessed using TROPOMI and OMI observations. Geophys. Res. Lett. 47, e2020GL087978. https://doi.org/10.1029/2020GL087978

Borsdorff, T., aan de Brugh, J., Pandey, S., Hasekamp, O., Aben, I., Houweling, S., Landgraf, J. (2019). Carbon monoxide air pollution on sub-city scales and along arterial roads detected by the Tropospheric Monitoring Instrument. Atmos. Chem. Phys. 19, 3579-3588. https://doi.org/ 10.5194/acp-19-3579-2019

Briber, B., Hutyra, L., Dunn, A., Raciti, S., Munger, J. (2013). Variations in atmospheric $\mathrm{CO}_{2}$ mixing ratios across a Boston, MA urban to rural gradient. Land 2, 304-327. https://doi.org/10.3390/ land2030304

Choi, S.H., Ghim, Y.S., Chang, Y.S., Jung, K. (2014). Behavior of particulate matter during high concentration episodes in Seoul. Environ. Sci. Pollut. Res. 21, 5972-5982. https://doi.org/10.1 007/s11356-014-2555-y

Clerbaux, C., Edwards, D.P., Deeter, M., Emmons, L., Lamarque, J.F., Tie, X.X., Massie, S.T., Gille, J. 
(2008). Carbon monoxide pollution from cities and urban areas observed by the Terra/MOPITT mission. Geophys. Res. Lett. 35, L03817. https://doi.org/10.1029/2007GL032300

Duren, R.M., Miller, C.E. (2012). Measuring the carbon emissions of megacities. Nat. Clim. Change 2, 560-562. https://doi.org/10.1038/nclimate1629

Ghim, Y.S., Chang, Y.S., Jung, K. (2015). Temporal and spatial variations in fine and coarse particles in Seoul, Korea. Aerosol Air Qual. Res. 15, 842-852. https://doi.org/10.4209/aaqr.2013.12.0362

Goldberg, D.L., Lu, Z., Streets, D.G., de Foy, B., Griffin, D., McLinden, C.A., Lamsal, L.N., Krotkov, N.A., Eskes, H. (2019). Enhanced capabilities of TROPOMI NO${ }_{2}$ : Estimating NOx from North American cities and power plants. Environ. Sci. Technol. 53, 12594-12601. https://doi.org/10. 1021/acs.est.9b04488

Hassler, B., McDonald, B.C., Frost, G.J., Borbon, A., Carslaw, D.C., Civerolo, K., Granier, C., Monks, P.S., Monks, S., Parrish, D.D., Pollack, I.B., Rosenlof, K.H., Ryerson, T.B., von Schneidemesser, E., Trainer, M. (2016). Analysis of long-term observations of NOx and CO in megacities and application to constraining emissions inventories. Geophys. Res. Lett. 43, 9920-9930. https://doi.org/10.1002/2016GL069894

Hutyra, L.R., Duren, R., Gurney, K.R., Grimm, N., Kort, E.A., Larson, E., Shrestha, G. (2014). Urbanization and the carbon cycle: Current capabilities and research outlook from the natural sciences perspective. Earth's Future 2, 473-495. https://doi.org/10.1002/2014EF000255

Jeong, Y.Y., Moon, T.H. (2014). Analysis of Seoul urban spatial structure using pedestrian flow data - comparative study with '2030 Seoul Plan'. J. Korean Reg. Dev. Assoc. 26, 139-158. Retrieved from https://www.dbpia.co.kr/

Kim, K.H., Woo, D., Lee, S.B., Bae, G.N. (2015). On-road measurements of ultrafine particles and associated air pollutants in a densely populated area of Seoul, Korea. Aerosol Air Qual. Res. 15, 142-153. https://doi.org/10.4209/aaqr.2014.01.0014

Kim, S., Hong, K.H., Jun, H., Park, Y.J., Park, M., Young, S. (2014). Effect of precipitation on air pollutant concentration in Seoul, Korea. Asian J. Atmos. Environ. 8, 202-211. https://doi.org/ 10.5572/ajae.2014.8.4.202

Kim, Y., Guldmann, J.M. (2011). Impact of traffic flows and wind directions on air pollution concentrations in Seoul, Korea. Atmos. Environ. 45, 2803-2810. https://doi.org/10.1016/j.atm osenv.2011.02.050

Konovalov, I.B., Berezin, E.V., Ciais, P., Broquet, G., Zhuravlev, R.V., Janssens-Maenhout, G. (2016). Estimation of fossil-fuel $\mathrm{CO}_{2}$ emissions using satellite measurements of "proxy" species. Atmos. Chem. Phys. 16, 13509-13540. https://doi.org/10.5194/acp-16-13509-2016

Kort, E.A., Frankenberg, C., Miller, C.E., Oda, T. (2012). Space-based observations of megacity carbon dioxide. Geophys. Res. Lett. 39, L17806. https://doi.org/10.1029/2012GL052738

Lama, S., Houweling, S., Boersma, K.F., Aben, I., van der Gon, H.A.C.D., Krol, M.C., Dolman, A.J., Borsdorff, T., Lorente, A. (2019). Quantifying burning efficiency in megacities using the $\mathrm{NO}_{2} / \mathrm{CO}$ ratio from the Tropospheric Monitoring Instrument (TROPOMI) Atmos. Chem. Phys. 20, 10295-10310. https://doi.org/10.5194/acp-2019-1112

Lamsal, L.N., Martin, R.V., Parrish, D.D., Krotkov, N.A. (2013). Scaling relationship for $\mathrm{NO}_{2}$ pollution and urban population size: A satellite perspective. Environ. Sci. Technol. 47, 78557861. https://doi.org/10.1021/es400744g

Le Quéré, C., Jackson, R.B., Jones, M.W., Smith, A.J.P., Abernethy, S., Andrew, R.M., De-Gol, A.J., Willis, D.R., Shan, Y., Canadell, J.G., Friedlingstein, P., Creutzig, F., Peters, G.P. (2020). Temporary reduction in daily global $\mathrm{CO}_{2}$ emissions during the COVID-19 forced confinement. Nat. Clim. Change 10, 647-653. https://doi.org/10.1038/s41558-020-0797-x

Mayer, H. (1999). Air pollution in cities. Atmos. Environ. 33, 4029-4037. https://doi.org/10.1016/ S1352-2310(99)00144-2

Moran, D., Kanemoto, K., Jiborn, M., Wood, R., Többen, J., Seto, K.C. (2018). Carbon footprints of 13000 cities. Environ. Res. Lett. 13, 064041. https://doi.org/10.1088/1748-9326/aac72a

Nguyen, H.T, Kim, K.H., Ma, C.J., Cho, S.J., Ryeul Sohn, J. (2010). A dramatic shift in $\mathrm{CO}$ and $\mathrm{CH}_{4}$ levels at urban locations in korea after the implementation of the natural gas vehicle supply (NGVS) program. Environ. Res. 110, 396-409. https://doi.org/10.1016/j.envres.2010.03.002

Park, C., Jeong, S., Park, H., Woo, J.H., Sim, S., Kim, J., Son, J., Park, H., Shin, Y., Shin, J.H., Kwon, S.M., Lee, W.Y. (2020). Challenges in monitoring atmospheric $\mathrm{CO}_{2}$ concentrations in Seoul using low-cost sensors. Asia-Pac. J. Atmos. Sci. https://doi.org/10.1007/s13143-020-00213-2 
Richter, A., Burrows, J.P., Nuss, H., Granier, C., Niemeier, U. (2005). Increase in tropospheric nitrogen dioxide over China observed from space. Nature 437, 129-132. https://doi.org/10.10 38/nature04092

Shi, X., Brasseur, G.P. (2020). The response in air quality to the reduction of Chinese economic activities during the COVID-19 outbreak. Geophys. Res. Lett. 47, e2020GL088070. https://doi.org/10.1029/2020GL088070

Silva, S.J., Arellano, A. (2017). Characterizing regional-scale combustion using satellite retrievals of $\mathrm{CO}, \mathrm{NO}_{2}$ and $\mathrm{CO}_{2}$. Remote Sens. 9, 744. https://doi.org/10.3390/rs9070744

Silva, S.J., Arellano, A.F., Worden, H.M. (2013). Toward anthropogenic combustion emission constraints from space-based analysis of urban $\mathrm{CO}_{2} / \mathrm{CO}$ sensitivity. Geophys. Res. Lett. 40, 4971-4976. https://doi.org/10.1002/grl.50954

Sim, S., Jeong, S., Park, H., Park, C., Kwak, K.H., Lee, S.B., Kim, C.H., Lee, S., Chang, J.S., Kang, H., Woo, J.H. (2020). Co-benefit potential of urban $\mathrm{CO}_{2}$ and air quality monitoring: A study on the first mobile campaign and building monitoring experiments in Seoul during the winter. Atmos. Pollut. Res. 11, 1963-1970. https://doi.org/10.1016/j.apr.2020.08.009

Smith, I.M. (1993). $\mathrm{CO}_{2}$ and climate change: An overview of the science. Energy Convers. Manage. 34, 729-735. https://doi.org/10.1016/0196-8904(93)90014-2

Suntharalingam, P. (2004). Improved quantification of Chinese carbon fluxes using $\mathrm{CO}_{2} / \mathrm{CO}$ correlations in Asian outflow. J. Geophys. Res. 109, D18S18. https://doi.org/10.1029/2003JD0 04362

Turnbull, J.C., Tans, P.P., Lehman, S.J., Baker, D., Conway, T.J., Chung, Y.S., Gregg, J., Miller, J.B., Southon, J.R., Zhou, L.X. (2011). Atmospheric observations of carbon monoxide and fossil fuel $\mathrm{CO}_{2}$ emissions from East Asia. J. Geophys. Res. 116, D24306. https://doi.org/10.1029/2011JD0 16691

United Nations Human Settlements Programme (2011). Cities and climate change: Global report on human settlements. Routledge.

Veefkind, J.P., Aben, I., McMullan, K., Förster, H., de Vries, J., Otter, G., Claas, J., Eskes, H.J., de Haan, J.F., Kleipool, Q., van Weele, M., Hasekamp, O., Hoogeveen, R., Landgraf, J., Snel, R., Tol, P., Ingmann, P., Voors, R., Kruizinga, B., Vink, R., Visser, H., Levelt, P.F. (2012). TROPOMI on the ESA Sentinel-5 Precursor: A GMES mission for global observations of the atmospheric composition for climate, air quality and ozone layer applications. Remote Sens. Environ. 120, 70-83. https://doi.org/10.1016/j.rse.2011.09.027

Worden, H.M., Cheng, Y., Pfister, G., Carmichael, G.R., Zhang, Q., Streets, D.G., Deeter, M., Edwards, D.P., Gille, J.C., Worden, J.R. (2012). Satellite-based estimates of reduced $\mathrm{CO}$ and $\mathrm{CO}_{2}$ emissions due to traffic restrictions during the 2008 Beijing Olympics. Geophys. Res. Lett. 39, L14802. https://doi.org/10.1029/2012GL052395

World Health Organization (WHO) (2020a). Director-General's opening remarks at the media briefing on COVID-19 - 11 March 2020. https://www.who.int/dg/speeches/detail/whodirector-general-s-opening-remarks-at-the-media-briefing-on-covid-19---11-march-2020 (accessed 5 July, 2020).

World Health Organization (WHO) (2020b). Coronavirus disease (COVID-19) weekly epidemiological update. https://www.who.int/docs/default-source/coronaviruse/situationreports/20200831-weekly-epi-update-3.pdf?sfvrsn=d7032a2a_4 (accessed 21 September, 2020).

Wunch, D., Wennberg, P.O., Toon, G.C., Keppel-Aleks, G., Yavin, Y.G. (2009). Emissions of greenhouse gases from a North American megacity. Geophys. Res. Lett. 36, L15810. https://doi.org/10.1029/2009GL039825

Xu, K., Cui, K., Young, L.H., Hsieh, Y.K., Wang, Y.F., Zhang, J., Wan, S. (2020a). Impact of the COVID19 event on air quality in central China. Aerosol Air Qual. Res. 20, 915-929. https://doi.org/10.4209/aaqr.2020.04.0150

Xu, K., Cui, K., Young, L.H., Wang, Y.F., Hsieh, Y.K., Wan, S., Zhang, J. (2020b). Air quality index, indicatory air pollutants and impact of COVID-19 event on the air quality near central China. Aerosol Air Qual. Res. 20, 1204-1221. https://doi.org/10.4209/aaqr.2020.04.0139

Xu, X., Jiang, Z., Li, J., Chu, Y., Tan, W., Li, C. (2020c). Impacts of meteorology and emission control on the abnormally low particulate matter concentration observed during the winter of 2017. Atmos. Environ. 225, 117377. https://doi.org/10.1016/j.atmosenv.2020.117377 
ORIGINAL RESEARCH

Zhang, R., Zhang, Y., Lin, H., Feng, X., Fu, T.M., Wang, Y. (2020). NOx emission reduction and recovery during COVID-19 in East China. Atmosphere 11, 433. https://doi.org/10.3390/atmos 11040433 